\title{
Influence of the features and encounters affecting PPA, 2007 on implementation in tertiary institutions in Bauchi State, Nigeria
}

\author{
${ }^{1}$ Aminu Umar Sa'ad, ${ }^{2}$ Prof Yakubu Ibrahim, ${ }^{3}$ Dr Musa M Muktar, ${ }^{4}$ Mustapha Umar Sa'ad \\ 1,2,3 Department of Quantity Surveying, Faculty of Environmental Technology, Abubakar Tafawa \\ Balewa University, Bauchi \\ Email 19aminuumarsaad86@gmail.com, ${ }^{2}$ yakubuibrahim33@yahoo.com, \\ ${ }^{3}$ mmmukhtar99@gmail.com \\ ${ }^{4}$ Department of Estate Management and Valuation, Faculty of Environmental Technology, \\ Abubakar Tafawa Balewa University, Bauchi \\ Email ${ }^{4}$ mustaphaumarsaad@gmail.com
}

\begin{abstract}
Public Procurement Act 2007 (PPA, 2007) embraces the prevailing public procurement legal framework in Nigeria passed in 2007 to reinforce competition among procurement practitioners, ensure strict observance to due process in public expenditure, block wastages and outflows of public funds arising from public contracts, and certify that the core procurement principles of accountability, clearness, honesty, equality, economy, and competition is achieved in public institutions in Nigeria. As such, this study aimed to evaluating the features and encounters on the implementation of the PPA, 2007 in tertiary institutions in Bauchi State. The study adopted quantitative approach using descriptive and exploratory design. Data were collected through questionnaire survey from 80 respondents using purposive sampling. The data collected were subjected to analysis using mean ranking to identify the features, encounters and the level of implementation of PPA, 2007. Also, multiple regression was been used to assess the influence of the features and encounters affecting PPA, 2007 on implementation. The study revealed that the features and encounters are highly significant with $52 \%$ and $56 \%$ effect size on the dependent variable. Also, the study indicated that implementation of PPA, 2007 and enforcement usage in the study area is moderate. Thus, the study recommends that PPA, 2007 be amended in such a way that appointment of procurement officers in all public institutions be clearly stated in terms of appointment criteria such as profession, academic qualification, and professional experience and qualifications. The result perhaps, will help eradicate the culture of having non-professionals with no procurement related expertise being saddled with the responsibility of coordinating procurement activities and processes in the public in institutions in Nigeria.
\end{abstract}

Keywords: Influence, encounters, PPA, 2007, implementation, tertiary Institutions

\section{Introduction}

In view of the importance of public procurement for service delivery and the role it plays in the economy globally public procurement accounts to $18.42 \%$ of the world GDP (Roodhooft \& Abbeela; Mahmood, 2010; Musa, Success \& Nwaorgu, 2014). Thai (2001) attributed that public procurement represents $9 \%-13 \%$ of the GDP in developing countries, Nigeria inclusive. However, for public building projects to thrive successfully in terms cost effectiveness, efficiency, and value 
for money, implementation of public procurement legal framework is vital. In Kenya, Intaher and Johanna (2012) exposed that aspects which demoralized the core purposes on which the public procurement reforms were carried out. Despite the tasks of obedience to the requirements of public procurement reforms, delivery of public services, such as public building projects can be effectively and efficiently achieved when the existing public procurement legal framework is firmly observed. Nigerian public procurement exercise was reported to have been unsuccessful and disorganized before the passage of the Public Procurement Act 2007 (PPA, 2007) as it was based on Treasury Circulars of 1958 which provided guidelines on public expenditure management (Onyema, 2012). As a result PPA, 2007 was enacted to uphold competition in tendering, operational planning, budgeting for public projects, and elevation of global best practice, ethics and ideals in the area of public procurement practice in Nigeria (Bayero, 2012). However, despite the enactment of PPA, 2007 public procurement exercise in Nigeria has not been active and transparent as envisaged, encounters such as high level of political meddling in contract management in Nigeria is obvious and this requires firm agreement to the public procurement law to correct the irregularities (Onyema, 2017). Hence, this study evaluate the implementation of the PPA, 2007 in tertiary institutions, with a view to improving the implementation process for effective service delivery. To achieve its aims the study outlined the following objectives:

i. To assess the level of PPA, 2007 implementation in tertiary institutions in the study area.

ii. To identify the features and encounters affecting PPA, 2007 implementation in tertiary institutions in the study area.

iii. To determine the impact of the features and encounters affecting PPA, 2007 on implementation in tertiary institutions in the study area.

\section{Literature Review}

\section{Key Features of the Provisions of Public Procurement Act 2007 and Compliance}

The PPA, 2007 stresses more on open competitive bidding in the process and award of public contract by the procuring entities, this is to endorse competition among bidders and provide impartial ground for the most qualified and responsive bidder to emerge in a more clear manner (Okunonghae \& Sunday, 2015). As such, the act affords open competitive bidding as the default method to be embraced in the process of public contract by the procuring entities. However, there are unique cases where methods other than the open competitive bidding process can be embraced as provided in the PPA, 2007 (Oyegoke \& Olayiwola, 2010; Ekweme, 2010). Such method include: The two-stage tendering Process; The restricted tendering process; Request for quotations for direct procurements; Emergency procurements and two-stage tendering process.

FG (2008) provides that a procuring entity shall engage in procurement by two-stage tendering in the following cases: where it is not practicable for the procuring entity to formulate exhaustive specifications for the goods or works involved in the procurement; where the procuring entity seeks tenders, proposals or offers on various means of meeting its needs in order to obtain the most acceptable result to its procurement needs; or where the appeal of the goods or works are subject to hasty technological developments, also FG (2008) revealed that in the PPA, 2007 that the restricted tendering process requires the procuring entity to obtain the approval of the BPP. The process applies if: (a) the goods, works or services are obtainable only from a narrow number of suppliers or contractors; (b) the time and cost needed to inspect and appraise a large number of 
Borneo Journal of Social Science \& Humanities

DOI: https://doi.org/10.35370/bjssh.2019.1.2-03

e-ISSN: 2682-8235

(C) 2018, UCTS Publisher.

Submitted: 10 September 2019

Accepted: 23 December 2019

Published: 31 December 2019

tenders is inconsistent to the value of the goods, works or services to be procured; or (c) the procedure is used as an allowance rather than a custom again, in the case of (a), similar to the basis for the two-stage process, the restricted tendering process is suitable where the procurement is fairly new in the country, or involves mutual technology. At the same time, while scenario (b) allows the entity to embrace economic or cost/benefit validations for embracing this process, scenario (c) is actually a matter of the entity's choice. As the word implies, the process involves only a narrow number of contractors being invited to bid. If scenario (a) is the situation in question, all contractors who can perhaps provide the goods or services, must be summoned by virtue of section 40(2)(a) of the Act. Where scenario (b) is the state giving rise to restricted tendering, the procuring entity must still find a way of involving in a non-discriminatory way for a number of contractors in the process, so as to certify active competition. It is praiseworthy of note that restricted tendering does not place a digit on the number of contractors the procuring entity invites to bid. In addition, Adeyeye (2014) and FG (2008) offers that nonetheless the provision of section 16(17), however, the BPP may refuse to issue a Certificate of No Objection to contract awarded on the account that the price is extreme. Thus, even offering the lowest price will not warrant that a bidder gets the contract. In fact, the Bureau may either direct that the procurement measures be totally annulled or that the procuring entity conduct a re-tender where it feels that the price is undue. Adeyeye (2014) concurred that to enrich transparency in public procurement practice and agreement, the procuring entities must conform to section 19 part V sub-section (a-j). Philemon (2014) submitted to have significant agreement to the requirements of procurement act certain necessities need to be fulfilled, such as; training and sensitization of procurement officers, officers input in tendering process, application of suitable procurement method, procurement staff expertise and capability in procurement procedure, appraisal of tender by procurement personnel, active monitoring and examining.

\section{Public Procurement and its Challenging Factors of Implementation}

Public Procurement Laws of most nations especially developing nations have not been able to achieve its anticipated purpose and this is as a result of the encounters, among others, faced by the participants in the implementation of the Acts due to the economic, social and political setting where the act is functioning (Olatunji, Olawumi \& Odeyinka, 2016). Fayomi (2013) and Onyema (2017) highlighted delusion and suspicion as burden trailing the public procurement legal framework victory in Nigeria. This was largely attributed to high level of exploitation or mishandling of public resources strictly linked up with the public sector procurement systems. Musa, Success and Nwaorgu (2014) identified narrow clearness of procurement processes of MDA's, shortage of technical talent and skills among the MDA's, refusal of the National Assembly to submit to the requirements of the act and regulation by the Bureau, and poor ethical morals in the service among others.

Onyema (2011) asserted that backers, especially, some Ministries, Departments and Agencies (MDAs) officials, consultants, contractors and service providers, politicians and indigenes where some projects are placed have declined to accept the variations in the new public procurement framework. Because the framework serve as a firm block to the old mandate of how public resources is being tapped in the name of contract. As a result, they still hire all sorts of maneuvers to disturb the practice during bid solicitation and appraisals and contract execution stages. Another tasks faced in the implementation of PPA, 2007 is political meddling from the 
political class, for instance the PPA, 2007 provides for the establishment of the National Council on Public Procurement (NCPP) saddled with the responsibility of considering and approving policies on public procurement, approving changes in procurement process to adjust to improvements in modern technology among others. However, ever since the enactment of PPA, 2007 into law the government has not establish the NCPP and this left the roles of the NCPP at the mercy of the Federal Executive Council (FEC) with the president as chairman and the ministers as members. Abdullahi (2017) reported that public officers handling public procurement duties are mostly not adequately familiar with the PPA, 2007 requirements and this has negative effects on implementation and obedience. Migosi, Ombuki, and Evusa (2013) stated that in Kenya lack of awareness of public procurement rules and regulation as preserved in the countries procurement laws is one of major trials that is facing extensive implementation of the procurement guidelines in their countries. Abdullahi (2017) also reported that some of the influences which could affect public procurement guidelines observance include; procurement participants level of awareness of the procurement guidelines as preserved in the PPA, 2007 requirements, and constant usage of traditional procurement system without recourse to the new procurement guideline requirements, communication between the bureau and public procuring entities, training and workshops among others.

\section{Procurement Rules Awareness}

Onyinkwa (2017) stated that for the procurement stakeholders and professionals to effectively follow the PPA, 2007 provisions, well-understanding through awareness is necessary. The level of compliance with a specified rules provide prove that the promoters are aware and familiar with the prescribed rules (Rose, Coakley \& Franks 2004). Procurement rules that is easy to comprehend measure the level of compliance among public purchasers and procurement stakeholders (Eyaa \& Oluka, 2011; Gelderman et al., 2006).

In contrast, lack of awareness among the procurement stakeholders leads to ineffective and inefficient performance of their expected obligations, this usually leads to undermining the provisions of the procurement rules by executive directors of public procurement entities (Onyinkwa, 2013). This situation is rampant among stakeholders and construction procurement professionals and project parties at public organizations in most African countries where project awards are influenced public office holders (Onyinkwa, 2013). Awareness is one of the major research constructs that determines compliance level with procurement rules (Boer \& Telgen, 1998; Gelderman et al., 2006; Shehu 2014). Reforming the public procurement sectors has suffered a setback as a result of lack of awareness to the extant provisions of the procurement rules, thus providing an appropriate and sound knowledge through training and workshops to procurement stakeholders and professionals will be an effective tool (Gelderman et al., 2006). 
Borneo Journal of Social Science \& Humanities

DOI: https://doi.org/10.35370/bjssh.2019.1.2-03

e-ISSN: 2682-8235

(C) 2018, UCTS Publisher.

Submitted: 10 September 2019

Accepted: 23 December 2019

Published: 31 December 2019

\section{Enforcement of Regulation}

Enforcement is the necessary steps or action taken by regulatory bodies to ensure compliance with a set rules/regulations (Zubcic \& Sims, 2011). Enforcement is an effective compliance instrument adopted by many studies to enhance compliance (Gunningham, 2005; Imperato, 2005; Zubcic \& Sims, 2011). Application of enforcement mechanism and increased of penalties significantly improve compliance with certain set rules (Tukamuhabwa, 2012; Zubcic \& Sims, 2011).

Developing counties like Nigeria, Sri Lanka, Bangladesh, and Venezuela were reported to have experienced more irregularities in public procurement processes due to non-enforcement of the appropriate procurement policies (Raymond, 2008; Tukamuhabwa, 2012). In addition, Okeahalam (2014) stated that among the developing countries, Nigeria, and Ghana are identified with weakness in respect to procurement regulation enforcement. To achieve substantial compliance to procurement regulations threat of legal sanctions might be necessary, followed by enforcement actions (Tukamuhabwa, 2012).

Enforcement naturally enhance abidance to certain rules. Thus, it has regarded as a fundamental element of any compliance regime (Gunningham, 2005; Sutinen \& Kuperan, 1999). Review mechanism have the tendency of motivating procurement entity staff, professionals, bidders and other participants to abide by the procedural guidelines in countries that have established procurement policies (Hui et al., 2011). However, in a situation where there is low penalties to defaulters or in countries where there is absent of effective detective review mechanism, ineffective implementation will be explored since legal violation may be profitable because of poor enforcement regime (Tukamuhabwa, 2012).

\section{Research Hypothesis}

Consequently, the following hypothesis were recommended;

i. There is moderate implementation of PPA, 2007 and enforcement usage in the study area.

ii. There is significant relationship between the independent variables and the dependent variable in the study area.

\section{Theoretical Framework}

The study adopted the Institutional Theory. The Institutional Theory is the traditional method that is used to inspect fundamentals of public procurement (Zachary \& Pamela, 2014). Scott (2004) identifies three supports of institutions as supervisory, normative and social reasoning. The supervisory support stresses the use of rules, laws and sanctions as enforcement mechanism, with expedience as basis for obedience. The normative support refers to norms and values with social obligation as the basis of obedience. The social reasoning support rests on mutual understanding on collective beliefs, symbols, joint understanding (awareness). Borrowing from this theory, public institutions in Nigeria are guided by rules and regulations with the PPA, 2007 guiding the procurement process and activities. From the three supports of institutions advocated by Scott (2004) obedience to laid rules and regulations, social influence and familiarity with the law can influence the implementation of PPA, 2007, as such, this study embraced enforcement usage mechanism, awareness, and norms and values as some of the influences affecting the implementation of PPA, 2007 in the study area. 


\section{Conceptual Framework}

Independent Variables

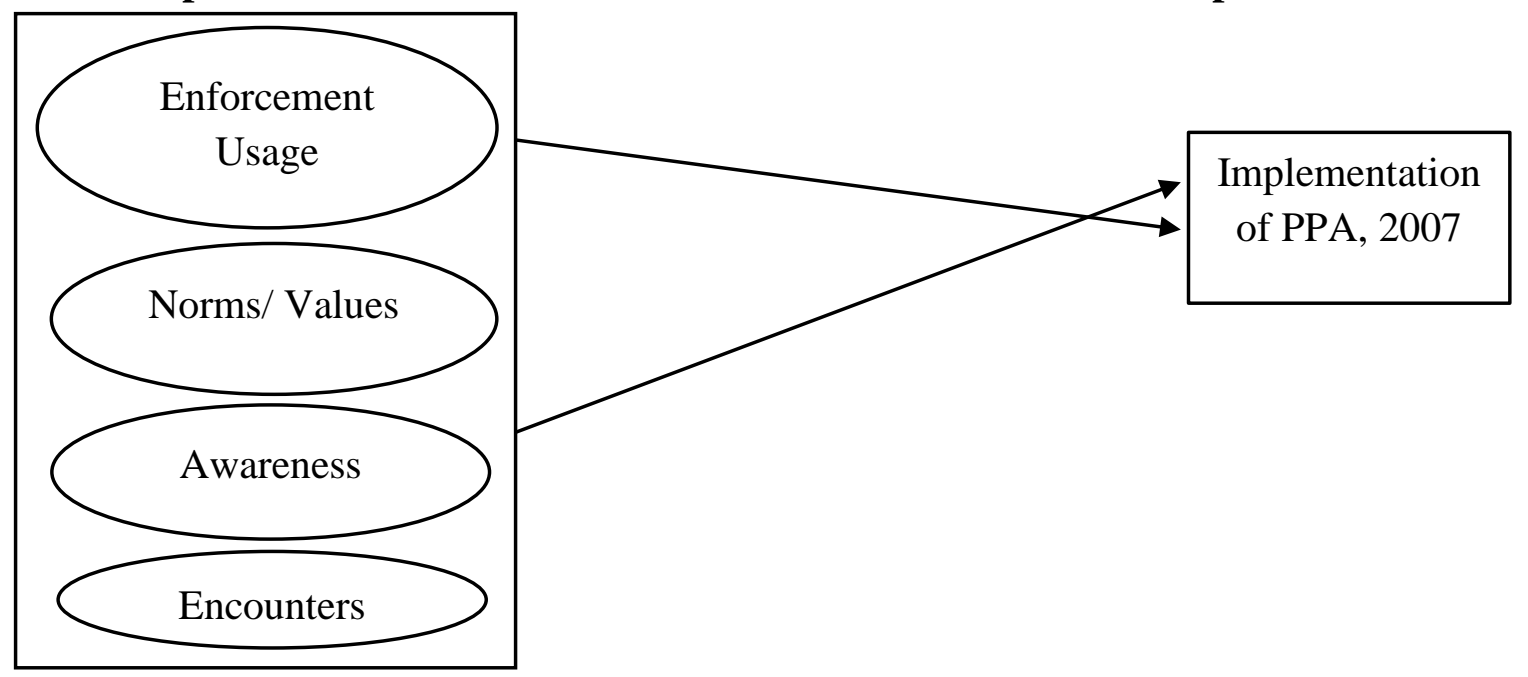

Figure 1: Conceptual Framework of the Study

Source: Author

\section{Methodology}

The study adopts exploratory design using quantitative approach; the strategy for the study was a survey, which involves the use of a questionnaire as an instrument of data collection. The questionnaire was administered individually to the respondents.

\section{Sample Design}

The study adopted purposive sampling method in the selection of the target respondents. Purposive sample method is where the researcher select a sample based on their knowledge about the study and population, participants are selected according to the needs for the study. Purposive sampling also concerns with collecting cases that are likely to give you the most information about the phenomenon you are studying (Statisticshowto, 2018). Purposive sampling was adopted for this study because only those who are involved in construction procurement activities in the study area can provide the most relevant information that will guide the study.

The study covered some selected tertiary institution in Bauchi State. The study population consists of procurement staffs in the study area, the study focused only on building professionals (Architects, Builders, Engineers and Quantity Surveyors) in A.T.B.U Bauchi, Bauchi State University Gadau, A.T.B.U. Teaching Hospital Bauchi, Federal Polytechnic Bauchi, Abubakar Tatari Ali Polytechnic Bauchi, FMC Azare and C.O.E Azare. The study sample frame consists of 101 procurement staffs in the study area. The table below shows the population and the sample size for the study. 
Table 1: Population and Sample Size of the Study

\begin{tabular}{lllll}
\hline S/no & Tertiary institution & Population (N) & Percentage (\%) & Sample (S) \\
\hline 1 & A.T.B.U Bauchi & 15 & 14.85 & \\
2 & A.T.B.U.T.H Bauchi & 20 & 19.80 & \\
3 & Fed. Poly. Bauchi & 18 & 17.82 & \\
4 & Bauchi State Uni. & 15 & 14.85 & \\
5 & A.T.A.P Bauchi & 10 & 9.90 & \\
6 & C.O.E. Azare & 12 & 11.88 & \\
7 & F.M.C. Azare & 11 & 10.89 & 80 \\
\hline
\end{tabular}

Source: Author

Krejcie and Morgan's (1970) table of determining sample size was adopted to determine the sample size based on the population of the study as shown in the table above.

The questionnaire design incorporates the use of closed-ended questions (Adeyeye, 2014; Philemon, 2014; Abdullahi, 2017; Jennifer, 2014; Addo, 2014; Olajide, Deji, \& Oluwaseyi, 2015, and Fayomi 2013). The closed-ended gives choice to a respondent ranging from 1 to 5 ideas rating (Likert-style) questions and standing. The questionnaire was personally distributed and retrieved in the study area. Mean ranking was adopted to identify the level of PPA, 2007 implementation, features affecting the implementation of PPA, 2007 and encounters facing the implementation of PPA, 2007 while multiple regression was adopted to determine the influence of impact of the features and encounters affecting the implementation of PPA, 2007 in the study area. Statistical Package for Social Science (SPSS, version 22) was adopted for statistical analysis of the data collected from the questionnaire survey.

\section{Findings}

\section{Questionnaire Administration and Return Rate}

The questionnaire for the study was administered to the target respondents in the selected institutions successfully, so also retrieval of the administered questionnaire as shown in the table below.

Table 2: Questionnaire response rate

\begin{tabular}{lcccc}
\hline Institution & $\begin{array}{c}\text { Questionnaire } \\
\text { administered }\end{array}$ & $\begin{array}{l}\text { Questionnaire } \\
\text { returned }\end{array}$ & $\begin{array}{c}\text { Questionnaire } \\
\text { unreturned }\end{array}$ & $\begin{array}{c}\text { Questionnaire } \\
\text { analyzed }\end{array}$ \\
\hline A.T.B.U Bauchi & 15 & 14 & 1 & 14 \\
A.T.B.U.T.H & 20 & 18 & 2 & 16 \\
STATE UNI. & 15 & 12 & 3 & 11 \\
A.T.A.P Bauchi & 10 & 6 & 4 & 6 \\
C.O.E Azare & 12 & 10 & 2 & 10 \\
F.M.C Azare & 11 & 9 & 2 & 9
\end{tabular}


Borneo Journal of Social Science \& Humanities

DOI: https://doi.org/10.35370/bjssh.2019.1.2-03

e-ISSN: 2682-8235

(c) 2018, UCTS Publisher.

Submitted: 10 September 2019

Accepted: 23 December 2019

Published: 31 December 2019

$\begin{array}{llllll}\text { FED. } & \text { POLY } & 18 & 15 & 3 & 15\end{array}$

Bauchi

\begin{tabular}{lllll}
\hline TOTAL & 101 & $84(83 \%)$ & $17(19 \%)$ & $81(80 \%)$ \\
\hline
\end{tabular}

Source: Author

Table 2 above indicates that a total number of one hundred and one (101) questionnaires were administered to staff involved in construction procurement in the study area. A total number of eighty three (83) questionnaires were successfully retrieved from the respondents. Seventeen (17) questionnaires were not returned from the field due to difficulty to reach some of the respondents in the respective study area. As a result of this, a total number of eighty one (81) questionnaires were used for analysis.

\section{Demographic Profile Information}

The demographic information of the respondents was analysed. These comprises gender, academic qualification, working experience, field of specialization and professional body registered. The results of the analysis were presented in the table below.

Table 3: Demographic Information of Respondent

\begin{tabular}{|c|c|c|c|c|}
\hline S/no & Code & Attributes & Frequency & Percentage \\
\hline \multirow[t]{2}{*}{1} & Gender & Male & 76 & 93.83 \\
\hline & & Female & 5 & 6.17 \\
\hline \multirow[t]{3}{*}{2} & Qualification & National Diploma/HND & 19 & 23.46 \\
\hline & & B. Tech/B. Sc Degree & 48 & 59.30 \\
\hline & & Master's and above & 14 & 17.28 \\
\hline \multirow[t]{4}{*}{3} & Working experience & Less than 3years & 12 & 14.81 \\
\hline & & 3-6years & 36 & 44.44 \\
\hline & & 7-10years & 19 & 23.46 \\
\hline & & More than 10years & 14 & 17.28 \\
\hline \multirow[t]{4}{*}{4} & Specialization & Architect & 22 & 27.16 \\
\hline & & Quantity surveyor & 38 & 46.91 \\
\hline & & Builder & 4 & 4.96 \\
\hline & & Engineer & 17 & 20.99 \\
\hline \multirow[t]{5}{*}{5} & Professional body & NIQS & 36 & 44.44 \\
\hline & & NIOB & 4 & 4.94 \\
\hline & & COREN & 11 & 13.58 \\
\hline & & NIA & 15 & 18.52 \\
\hline & & Unregistered & 15 & 18.52 \\
\hline
\end{tabular}

Source: Author 
As indicated in Table 3, about $94 \%$ of the respondents were males; while $6 \%$ were females. Therefore, the study observed that most of the staff involved in construction procurement in the study area were males. Reason for differences in response rates by sex of the respondents could probably be as a result of the nature of construction work/activities where females rarely practice or participate in the process. In respect of the respondents' qualification the study shows that about $23 \%$ of the respondents have National Diploma/HND, 59\% of the respondents possesses B.Tech/B.sc degree, while 17\% holds Master's Degree and above. However, the overall implication is that many of the respondents are literate and this suggests that the respondents were intellectually capable to respond to questions asked in this study. In terms of working experience of the respondent in the study area table 5 shows that $15 \%$ of the respondents have less than 3years working experience, $44 \%$ have between 3-6years working experience, $23 \%$ are between 7 -10years working experience while $17 \%$ possesses more than working experience in the study area. The analysis indicates that most of the respondents within the study area have average working experience and this aids the respondents to respond to the questionnaire appropriately. Also, data from table 3 indicate that about $27 \%$ of the respondents were Architects, $47 \%$ of the respondents were Quantity surveyors, and 5\% of the respondents were Builders while $21 \%$ of the respondents were Engineers. The analysis shows that almost have half of the respondents were Quantity surveyors then followed by Architects, then Engineers and Builders have the least number among the respondents in the study area. This suggests that all respondents were members of building team in the construction industry and as such have requisite knowledge of construction procurement. Importantly, the study indicates that $44 \%$ of respondents among the Quantity surveyors have registration with NIQS, $5 \%$ of the respondents were Builders and have registration with NIOB, 14\% of the respondents among the Engineers have registration with COREN and 19\% of the respondents among the Architect have registration with NIA, while 19\% of the respondent comprising Architects, Quantity surveyors, Builders and Engineers do not have registration with their respective professional bodies. This indicates that among all the respondents targeted in the study area $82 \%$ have registration with their respective professional bodies while $18 \%$ do not have registration with their professional bodies.

\section{Reliability and Validity Test}

For the purpose of this study a pre-test was done using content validity and internal consistency reliability test (Cronbach's coefficient alpha) to determine the reliability and validity of the questionnaire. The test revealed possible difficulty encountered during actual data and information collective exercise, so that precautionary measures would be taken. For the pretest and content validity of the instrument (content-related evidence) senior academic staff, specialist and expert on the topic under study were consulted to determine the appropriateness of the items of the instrument.

The reliability result of each construct of the field survey is shown in the table below.

\begin{tabular}{ll}
\hline Construct & Field survey \\
\hline Implementation of PPA, 2007 & 0.838 \\
Enforcement usage & 0.731 \\
Awareness & 0.832
\end{tabular}


Borneo Journal of Social Science \& Humanities

DOI: https://doi.org/10.35370/bjssh.2019.1.2-03

e-ISSN: 2682-8235

(c) 2018, UCTS Publisher.

Submitted: 10 September 2019

Accepted: 23 December 2019

Published: 31 December 2019

Observation of norms and values

0.862

Encounters

0.761

\section{Table 4: Cronbach's Alpha of Field Survey}

Source: Author

The reliability test result of the field survey was analyzed based on the finding of the study Cronbach's alpha as suggested by Pallant (2011). Overall Cronbach's alpha for the questionnaire was 0.731-0.892. This shows that the questionnaire as a whole is reliable and acceptable.

\section{Level of Implementation of PPA, 2007 in the Study Area.}

Descriptive statistics based on mean ranking was carried out to explore the level of PPA, 2007 implementation in the study area. The result was shown in the table below.

Table 5: Level of PPA, 2007 Implementation

\begin{tabular}{lccccc}
\hline PPA, 2007 provisions & Mean & $\begin{array}{c}\text { Std. } \\
\text { Deviation }\end{array}$ & Rank & Remark \\
\hline $\begin{array}{l}\text { Advertisement of tender invitation } \\
\text { Tender evaluation according to bidding }\end{array}$ & 3.8133 & 1.04630 & $1^{\text {st }}$ & High \\
requirement & 3.2259 & 1.04222 & $2^{\text {nd }}$ & Moderate \\
$\begin{array}{l}\text { Procurement plan linked to budget } \\
\text { Notification of winners of bids }\end{array}$ & 3.2032 & 1.05538 & $3^{\text {rd }}$ & Moderate \\
$\begin{array}{l}\text { Notification of date and time for bid opening } \\
\text { Compliance with institution's procurement }\end{array}$ & 3.0884 & 1.02102 & $4^{\text {th }}$ & Moderate \\
procedures & 2.9412 & 1.06446 & $6^{\text {th }}$ & Moderate \\
$\begin{array}{l}\text { Procurement staff experience on procurement } \\
\text { process }\end{array}$ & 2.9412 & 1.22171 & $7^{\text {th }}$ & Moderate \\
$\begin{array}{l}\text { Procurement staff participation in tendering } \\
\text { process }\end{array}$ & 2.9116 & 1.22171 & $8^{\text {th }}$ & Moderate \\
$\begin{array}{l}\text { Publication of contract award for bidders to see } \\
\text { Application of transparent rules for the }\end{array}$ & 2.9116 & 1.26489 & $9^{\text {th }}$ & Moderate \\
selection of bidders & 2.7522 & 1.26489 & $10^{\text {th }}$ & Moderate \\
Notification of losers of bids & & & & & \\
Using internal board to display information & 2.56322 & 1.12875 & $12^{\text {th }}$ & Low \\
\hline
\end{tabular}

Mean value index $=3.0$

Source: Author

As presented in Table 2, the data shows that the mean value ranged from a mean value of 3.8133 to the lowest mean value of 2.56322 . It can be perceived from the table above that advertisement of tender invitation has the highest mean value of 3.8133, whereas tender evaluation according to bidding requirement, procurement plan linked to budget, down to notification of winners of bid were rated moderate in the study area having their mean values ranges from 3.22592.6494. Using of internal board to display information was rated low in the study with a mean 
value of 2.56322. This study adapted the mean score decision interval based on the mechanism of Kasim, Ishiyaku, Harir \& Usman (2013), Hassanain and Iftikhar (2015)

Also, the encounters influencing PPA, 2007 implementation in the study area, Table 3 highlights the response of the respondents on the contests.

Table 3: Encounters Influencing the Level of PPA, 2007 Implementation

\begin{tabular}{lcccc}
\hline Encounters & Mean & $\begin{array}{c}\text { Std. } \\
\text { Deviation }\end{array}$ & Rank & Remark \\
\hline Political interference & 4.3607 & 0.79651 & $1^{\text {st }}$ & High \\
Corruption & 3.9344 & 1.10859 & $2^{\text {nd }}$ & High \\
Complexity of procurement regulations & 3.8852 & 1.06612 & $3^{\text {rd }}$ & High \\
Public perception of procurement as waste & 3.7377 & 0.98152 & $4^{\text {th }}$ & High \\
Managing ethical standard by stakeholders & 3.6393 & 1.09594 & $5^{\text {th }}$ & High \\
Size and complexity of procurement & 3.5246 & 1.17766 & $6^{\text {th }}$ & High \\
Incompetency of the procurement staff & 3.4426 & 0.97510 & $7^{\text {th }}$ & High \\
Procurement officials not part of decision & 3.4098 & 1.15517 & $8^{\text {th }}$ & Moderate \\
making & & & & \\
Delay of response from BBP & 3.3607 & 1.19333 & $9^{\text {th }}$ & Moderate \\
Shortage of procurement practitioners & 3.3115 & 1.00898 & $10^{\text {th }}$ & Moderate \\
\hline
\end{tabular}

Mean value index $=3.23$

Source: Author

As presented in Table 3, the data shows that the mean value ranged from a high mean value of 4.3607 to the lowest mean value of 3.3115. It can be perceived from the table that among the encounters listed, political interference, corruption, complexity of procurement regulations, public perception of procurement as waste, managing ethical standard by stakeholders, size and complexity of procurement, and incompetency of the procurement staff were rated high with mean values ranging from 4.3607-3.4426. Furthermore, procurement staff not part of decision making, delay of response from $\mathrm{BBP}$, and shortage of procurement practitioners were found to have moderate influence on PPA, 2007 implementation in the study area having their mean value of 3.4098-3.3115. This study adapted the mean score decision interval based on the mechanism of Kasim, Ishiyaku, Harir \& Usman (2013), Hassanain and Iftikhar (2015) and Abdullahi (2017).

Also, the table below shows the influence of the features and encounters on implementation of PPA, 2007 in tertiary institutions in the Bauchi State. The features identified in the study area are based on enforcement usage, norms and values, and awareness. The individual contribution of each variable was also shown in the table below. 
Table 6: Influence of Features Affecting PPA, 2007 and Encounters on Implementation of PPA, 2007

\begin{tabular}{|c|c|c|c|c|c|c|c|}
\hline Model & $\mathrm{R}$ & R Square & Adjusted R Square & $\begin{array}{l}\text { Std. Error of } \\
\text { Estimate }\end{array}$ & the $\mathrm{F}$ & $\mathrm{df}$ & Sig. \\
\hline 1 & .586 & .343 & .308 & .52756 & 15.011 & 2,79 & .000 \\
\hline
\end{tabular}

Table 6 shows that $\mathrm{R}$ square value demonstrate how much of the variance in the dependent variable, PPA, 2007 implementation value is explained by the independent variables of enforcement usage, awareness, and norms and values on PPA, 2007 implementation. In this case, the value was $\left.\mathrm{r}^{2}=.343, \mathrm{f}(2,79)=15.011, \mathrm{p}<.001\right)$. This indicates that the independent variables have significant effect on the implementation of PPA, 2007.

Table 7: Individual Effects of Features and Encounters Affecting PPA, 2007 on Implementation

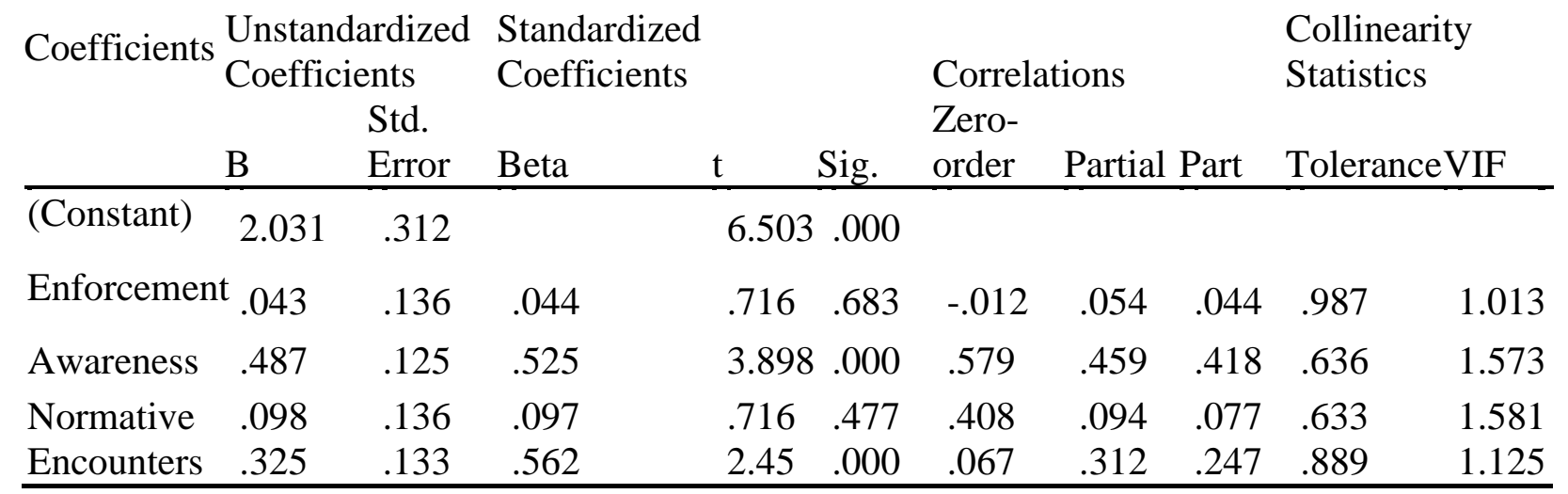

Dependent Variable: Implementation of PPA, 2007

Source: Author

The analysis in Table 7 further indicates the effects of the independent variables on the dependent variable, the table indicates that the variable with largest beta value in the standardized coefficients is .562 for encounters and .525 for awareness. It further shows that encounters and awareness variable are statistically significant $(\mathrm{p}<.001)$ as recommended by Pallant (2011) showing unique contribution to the equation. In contrast, norms and values variable has lower positive beta value of .097 which is insignificant $(\mathrm{p}=.477)$ contribution in explaining the dependent variable (implementation of PPA, 2007). Finally, enforcement has the lowest positive beta value of .044 which is also not significant where $\mathrm{p}=.683$. The analysis indicates that encounters and awareness are strongly significant having $56 \%$ and $52 \%$ effect size on the dependent variable. 
Borneo Journal of Social Science \& Humanities

DOI: https://doi.org/10.35370/bjssh.2019.1.2-03

e-ISSN: 2682-8235

(C) 2018, UCTS Publisher.

Submitted: 10 September 2019

Accepted: 23 December 2019

Published: 31 December 2019

\section{Discussion}

The study revealed that the implementation of the PPA, 2007 and enforcement usage in the study area is moderate based on the mean value index obtained after the analysis. This indicates that PPA, 2007 implementation has not been effective in the study area as expected. In a similar findings, Florence (2018) reported that compliance to public procurement Act 2007 is relatively high in public entities in Nigeria, but lack of structures and facilities to ease procurement process and pervading corruption in Nigeria have hindered the effective implementation of the Act.

Also, the study findings revealed that the impact of the features and encounters affecting PPA, 2007 on implementation was found to be highly significant, having awareness and encounters with $52 \%$ and $56 \%$ effect size on the dependent variable. The findings of the study also revealed positive relationship between the independent variables and the dependent variable in the study area. Thus, the study concurred that the independent variables have significant effect on the dependent variable in the study area. The study further disclosed that awareness and encounters returned a P-value of .000 (which is less than .005) this indicates that there is statistically significant relationship between awareness, encounters, and PPA, 2007 implementation while enforcement and normative has P-value of .683 and .477 (which is greater than .005) this specifies that there is no statistically significant connection between normative and PPA, 2007 implementation in the study area.

Abdullahi, Abdul Aziz and Atasya (2015) have a similar finding with this study on level of awareness of procurement staff, the study finding affirmed that familiarity with the public procurement guidelines by procurement stakeholders determines the success or failure of compliance with the provisions of the public procurement law and its implementation. Olatunji, Olawumi and Odeyinka (2016) in their findings similar to this study attributed absence of political will to derive developmental changes and prevalence of corruption in Nigerian as having dare consequence on the implementation of the PPA in the Nigerian public sector.

\section{Conclusion and Recommendations}

The study revealed that level of PPA, 2007 implementation and enforcement usage in the study area is moderately implemented and encounters affecting the implementation of the PPA, 2007 was found to be high. The study further shows that among the features (enforcement usage and awareness) only awareness and encounters have effect on the PPA, 2007 implementation exhibited P-values less than.001, indicating that there is statistically significant relationship among the variables and PPA, 2007 implementation.

It can be concluded that among the features only awareness and encounters have significant relationship with PPA, 2007 implementation in the study area, while demonstrating the impact of each feature (enforcement usage, norms and values, and awareness) on the PPA, 2007 implementation. The study recommends that the government should be able to constitute the National Council of Public Procurement (NCPP), as provided in the PPA, 2007 which is an important implementation arm of the Act. As political meddling is one of the major encounters faced in the smooth implementation of the act in most public institutions, the constitution of NCPP will cease the executive the opportunity of meddling with the award of public contracts. Also, the PPA, 2007 needs to be amended in such a way that the appointment of public procurement officers 
Borneo Journal of Social Science \& Humanities

DOI: https://doi.org/10.35370/bjssh.2019.1.2-03

e-ISSN: 2682-8235

(c) 2018, UCTS Publisher.

Submitted: 10 September 2019

Accepted: 23 December 2019

Published: 31 December 2019

in all public institutions will be clearly stated in terms criteria of appointment such as; profession, academic qualification, and professional qualification and experience. This will help eliminate the culture of having non-professionals with no procurement related expertise being saddled with the responsibility of coordinating procurement activities and processes in the public institutions in Nigeria.

\section{References}

Abdullahi, N. Z. (2017). Mediation Model for the Determination of Non-Compliance with Public Procurement Guidelines and Cost Performance of Construction Projects. Malaysia: Abdullahi Nafiu Zadawa; Thesis Submitted in Fulfillment of the Requirements for the Degree of Doctor of Philosophy.

Abdullahi, N. Z., Abdul Aziz, H., \& Atasya, O. (2015). Determinants of Compliance with Public Procurement Guidlines in the Nigerian Construction Industry. Journal Teknologi, 2.

Addo, A. F. (2014). Compliance and Implementation Challenges of the Public Procurement Act 663 in District Education Offices. Ashanti, Ghana: A thesis Submitted to the Department of Building Technology, Kwame Nkrumah University of Science and Technology in Partial Fulfillment of the Requirement for the award of Master of Science in Procurement Management.

Adeyeye, A. (2014). Governance Reform and the Challenges of Implementing Public Procuement Law Regime Across Nigerian States and Local Governments. International Jornal of Public Administration and Manangement Research, 26-27.

Bayero, B. K. (2012). Public Procurement Reform and Good Governance in Nigeria; Department of Public Administration, Faculty of Management Science, Usman Danfodio University, Sokoto. Sokoto: Bayero Bukkuyum Kasim.

Boer, N., \& Telgen, J. (1998). Purchasing Practice in Dutch Municipalities. International Journal of Purchasing and Materials Management, 34(1), 31-36.

Fayomi, O. I. (2013). Public Procurement and Due Process Policy in Nigeria: Thrust, Prospect and Challenges. Journal of Social Science and Humanities, 1-3.

FG. (2008). Public Procurement Act 2007. Lagos: Federal Government of Nigeria.

Gelderman, C. J., Ghijsen, P. W., \& Brugman, M. J. (2006). Public Procurement and EU Tendering Directive-Explaining Non-compliance. Internal Journal of Public Sector Management, 19(7), 702-714.

Gunningham, N., \& Kagan, R. A. (2005). Regulations and Bussiness Behaviour. Law and Policy, 27, 213-218.

Hui, W. O., Normah, O., Rahman, R., \& Haron, N. (2011). Procurement Issues in Malaysia. International Journal of Public Sector, 567-593.

Intaher, A. M., \& Johanna, B.-W. A. (2012). Procurement Challenges in the South African Public Sector. Journal of Transport and Supply Management, 242-246.

Jennifer, P. (2014). Regulative, Normative and Cognitive Elements or Organizations: Implication for Managing Change. Journal of Management and Organizational Studies, Volume 1, Number 2; 59-63.

Kashim, R., Ishiyaku, B., Harir, A., \& Usman, H. (2013). Perfprmance Evaluation of Tangible and Intangible Environmental Factors for Sustainable Housing Development in 
Borneo Journal of Social Science \& Humanities

DOI: https://doi.org/10.35370/bjssh.2019.1.2-03

e-ISSN: 2682-8235

(c) 2018, UCTS Publisher.

Submitted: 10 September 2019

Accepted: 23 December 2019

Published: 31 December 2019

Developing Countries. Proceedings of International Conference, (pp. 185-196).

Retrieved from lectlaw website: www.lectlaw.com

Musa, S. J., Success, B. E., \& Nwaorgu, I. A. (2014). The Public Procurement Reform in Nigeria: Implementation \& Compliance Challemges. Journal of Asian Bussiness, 157.

Okeahalam, C. C. (2014). Corporate Governance and Disclosure in Africa: Issues and Challenges. Journal of Financial Regulation and Compliance, 12(4), 359-370.

Okuonghae, E. O., \& Sunday, O. I. (2015). The Impact of Public Procurement Act on Government Accountability in Nigeria. Journal of Political science and Leadership Research, 6.

Olajide, F., Deji, R. O., \& Oluwaseyi, A. A. (2015). Assessment of Challenges Facing the Effective Operation of the Nigerian Public Procurement Act 2007. International Journal of Economics, Commerce and Management, 12.

Olutuji, S. O., Olawumi, T. O., \& Odeyinka, H. A. (2016). Nigerian Public ProcurementPuissant Issues \& Projected Amendment. Public Policy \& Administration Research, Volume 6, 78.

Onyema, M. E. (2011). Challenges and Propects of Public Procurement Practice in Nigerian. Abuja: Nigeriaworld.

Onyema, M. E. (2017, June 12). Nigeriworld. Retrieved from Nigeriaworld Web site: www.nigeriaworld.com: A decade of the Implementation of the Public Procurement Act 2007 in Nigeria; An Appraisal

Oyegoke, A., \& Olayiwola, M. A. (2010). The Effect of Public Procurement Act on Budget Appropriation on Project Delivery in NIgeria \& its Subsequent Effects on Supply Chain. Journal of Supply Chain Management, 1-6.

Philemon, K. C. (2014; Page 39-40). Public Procurement Procedures and Supply Chain Performance in State Corporations in Kenya. Nairobi, Kenya: A Research Project Submitted in Partial Fulfillment of the Requirement for the Award of Degree of Masters of Bussiness Administration to School of Bussiness, University of Nairobi, Kenya.

Raymond, J. (2008). Bechmarking in Public Procurement; Benchmarking. An Internal Journal, $782-793$.

Shehu, A. S. (2014). An Overview of Public Procurement Guidelines in Nigeria. A Paper Presnted at the Institute of Quantity Surveyors National Seminar 'Procurement of Construction Works and Services'- Adapting to Contemporary Challenges. Adapting to Contemporary Challenges, (pp. 23-34). Gombe International Hotel, Gombe State.

Thai, K. V. (2001). Public Procurement re-examined. Journal of Public Sector, 9-50.

Tukamuhabwa, B. R. (2012). Antecendents and Consequences of Public Procurement Noncompliance Behaviour. Journal Economics and Behavioural Studies, 4(1), 34-46.

Zachary, B. A., \& Pamela, N. M.-g. (2014). Public Procurement Legal Framework Implementation Challenges and Organizational Performance. DBA Africa Management Review, 105-107; Vol. 4 No. 2.

Zubcic, J., \& Sims, R. (2011). Examining the Link Between Enforcement Activity and Corporate Compliance by Australian Companies and the Implications for Regulators. International Journal of Law and Management, 53(4), 299-308. 